\title{
PROTOYPE APLIKASI DATA SUMBER DAYA MANUSIA(SDM) UNTUK PENYEDIA LAYANAN JASA ASISTEN RUMAH TANGGA DI BANJARMASIN
}

\author{
Rina Alfah \\ Fakultas Teknologi Informasi, Universitas Islam Kalimantan MAB \\ Email : rina.alfah.05@gmail.com
}

\begin{abstract}
Abstrak
Untuk membantu mempermudah Penyedia layanan jasa Baby Sitter dalam mendata para calon BS (Baby Sitter) dan ART (Asisten Rumah Tangga) maka perlu adanya sebuah sistem Komputer pada tempat tersebut. Untuk itu maka kami merancang sebuah aplikasi dengan menggunakan pemrograman power builder dan mysql ,sebuah aplikasi Data SDM Untuk penyedia layanan jasa Baby sitter dan asisten rumah tangga. Dengan ada nya aplikasi ini diharapkan jika ada permasalahan dari baby sitter ataupun asisten rumah tangga dengan orang yang memakai jasa mereka ,misalnya kasus kekerasan pada anak atau pencurian dirumah mereka, maka penyedia jasa bisa langsung mencari data lengkap personal yang bersangkutan dengan cepat. Selain itu aplikasi ini mencakup data pribadi/personal (curriculum vitae), penilaian kerja, dan data transaksi penggajihan untuk BS dan ART setiap bulannya.
\end{abstract}

Keywords: Aplikasi, Baby Sitter, MySQL, Power Builder, Transaksi

\section{PENDAHULUAN}

Dalam membantu seorang Ibu yang bekerja sebagai wanita karir dalam mengasuh anak yang masih bayi atau yang balita, maka sangat di perlukan suatu penyedia layanan baby sitter dan ART. selama ini biasanya masih mencari secara perorangan saja yaitu mendatangi orang-orang yang mau bekerja sebagai babysitter atau ART tersebut. Padahal faktanya banyak perilaku yang tidak diharapkan dari mereka yang terjadi dilapangan seperti kekerasan pada anak atau balita dikarenakan tidak adanya pihak yang bertanggung jawab dalam membimbing mereka sebagai baby sitter yang baik dan benar . maka kami ingin membuat sebuah rancangan aplikasi yang bisa dipakai untuk membantu penyedia layanan baby sitter dan ART dibanjarmasin . Dengan adanya aplikasi ini diharapkan dapat membantu mempermudah penyalur Baby Sitter dalam mendata para calon BS dan ART nantinya sebelum disalurkan ke sebuah keluarga yang memakai jasa mereka . pada aplikasi ini nantinya akan didata berbagai macam penilaian baik penilaian pribadi/personal (curriculum vitae), penilaian kerja, dan data transaksi penggajihan untuk BS dan ART setiap bulannya.

Berdasarkan latar belakang diatas, maka perlu suatu langkah untuk mempermudah pihak Penyedia layanan BabySitter (BS) dan Asisten Rumah tangga (ART) untuk mendata para pegawai untuk calon BS atau ART seperti yang biasa dilakukan oleh sebuah HRD (Human Resource Development) pada sebuah perusahaan yaitu Modul SDM yaitu data pegawai calon Babysitter dan ART atau pun yang sudah disalurkan . modul SDM berupa aplikasi berbasis desktop dengan beberapa menu yang akan memudahkan pihak penyedia layanan untuk mendata pegawai calon Babysitter/ BabySitter dan ART nantinya.

Beberapa kendala yang dihadapi jika pihak penyedia layanan jasa baby sitter dan ART tidak menyediakan sebuah system komputerisasi untuk SDM para Baby sitter dan ART yang akan disalurkan yaitu data yang susah ditemukan karena dilakukan secara manual, tidak lengkapnya informasi dari data personal/pribadi masing-masing tentunya akan menyulitkan pihak yang bertanggung jawab 
yaitu sang penyedia layanan untuk melakukan sanksi atau pun pidana jika terjadi hal yang tidak diingin/pelanggaran terhadap ketentuan perusahaan.

Tujuan dari penelitian ini adalah membuat sebuah Perancangan Aplikasi Data SDM Untuk Penyedia Jasa Layanan BabySitter Dan ART Di Banjarmasin.

Adapun Manfaat yang diharapkan dari penelitian ini yaitu sebuah aplikasi yang dapat memudahkan pihak penyedia layanan jasa BabySitter dan ART dalam mengarsipkan data SDM karyawannya baik yang belum disalurkan (karyawan baru) ataupun yang sudah bekerja dirumah yang membutuhkan jasa mereka.

\section{METODE PENELITIAN}

Pengumpulan data sangat lah penting dalam sebuah penelitian. Ketersediaan data akan sangat menentukan dalam proses pengolahan dan analisa selanjutnya. Karenanya, dalam pengumpulan data harus dilakukan teknik yang menjamin bahwa data diperoleh itu benar, akurat dan bisa dipertanggungjawabkan sehingga hasil pengolahan dan analisa penelitian. Untuk penelitian kami akan melakanakan beberapa proses yaitu:

Observasi.

Pengumpulan data dilakukan dengan cara observasi secara langsung ke objek penelitian yaitu Sebuah Yayasan Penyedia jasa layanan BabySitter Dan ART banjarmasin

\section{- Interview}

Melakukan Interview kepada pihak-pihak yang terlibat secara langsung dan berkaitan dengan objek penelitian yaitu pihak terkait yang berhubungan dengan penelitian ini

\section{- $\quad$ Studi Pustaka}

Membaca literatur-literatur baik buku ataupun sumber studi pustaka lainnya yang bisa menjadi sumber informasi yang berguna untuk pengumpulan data dan penelitian.

Tahapan yang harus dilakukan untuk penelitian ini antara lain :

1. Menentukan Objek penelitian yang akan diteliti dan menentukan masalah yang akan diidentifikasi dengan solusi permasalahan yang akan diterapkan ke objek penelitian.

2. Pengajuan proposal untuk penelitian
3. Mengakaji ulang teori yang sudah disetujui dan mulai melakukan pengumpulan data premier serta data sekunder untuk penelitian objek lebih lanjut.

4. Melakukan Pengolahan data-data yang sudah dikumpulkan serta menganalisa kebutuhan system untuk mendukung pembuatan aplikasi yang sudah menjadi tujuan.

5. Membuat rancangan Aplikasi

6. Melakukan testing dan implementasi system serta Pengujian Alat

7. Melakukan revisi atau perbaikan baik program atau pun alat jika diperlukan

8. Pembuatan laporan penelitan

9. Mengikuti Seminar hasil penelitian.

Tahapan Pembuatan Sistem

Analisa Sistem

Dalam ,membuat rancangan aplikasi ini diperlukan perencanaan yang baik agar dihasilkan sistem yang dapat berjalan optimal. Untuk tahap perencanaan nya adalah sebagai berikut:

Tujuan pembuatannya adalah membuat sebuah Aplikasi Data SDM Untuk Penyedia Jasa Layanan BabySitter Dan ART Di Banjarmasin yang berguna untuk mempermudah pengarsipan serta penyimpanan data-data yang mungkin suatu saat akan diperlukan kembali misalnya bila ada permasalahan dari si Baby sitter atau Asisten Rumah tangga yang disalurkan, maka akan cepat mencari data untuk menganalisa nya. Metode penelitian dalam hal ini meliputi perancangan yang kemudian diwujudkan dengan menggunakan software Pemrograman PowerBuilder Versi 7 dengan database MySql.

Desain Sistem

Dalam mendesain sebuah Aplikasi Penilaiaan dan pelaporan perkembangan murid ini, diperlukan beberapa komponen antara lain :

a. Perancangan Sistem Context Diagram Data Flow Diagram(DFD)

Data flow diagram adalah gambaran sistem secara logikal. Gambaran ini tidak tergantung pada perangkat keras, perangkat lunak, struktur data atau organisasi file. Keuntungan menggunakan data flow 
diagram adalah memudahkan pemakai atau user yang awam di bidang komputer untuk mengerti sistem yang akan dibuat. Diagram Flow Data dibuat untuk menggambarkan tahap - tahap proses yang ada di dalam diagram konteks secara terperinci. Diagram alir data(Data Flow Diagram) digunakan untuk menggambarkan Sistem informasi secara mudah melalui gambar yang lebih mudah di mengerti. DFD terdiri atas komponen entitas eksternal dalam bentuk kotak persegi panjang. Proses dalam kotak persegi panjang yang sudutnya melengkung atau bentuk lingkaran, alir bentuk garis panah, dan simpanan data (data store) dalam bentuk dua garis sejajar atau kotak persegi panjang dengan satu terbuka. Rancangan Analisa Aplikasi Data SDM Penyedia layanan jasa adalah seperti pada diagram berikut :

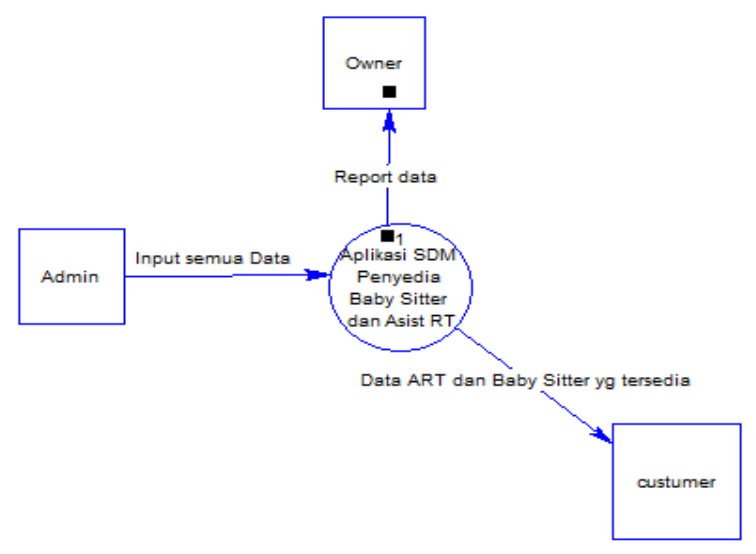

Gambar 1. Diagram konteks kebutuhan sistem

Flowchart

untuk mendukung aplikasi data SDM

Flowchart merupakan suatu diagram penyedia layanan jasa BS dan ART

yang menggambarkan alur kerja suatu sistem. Berikut flowchart yang dibuat 


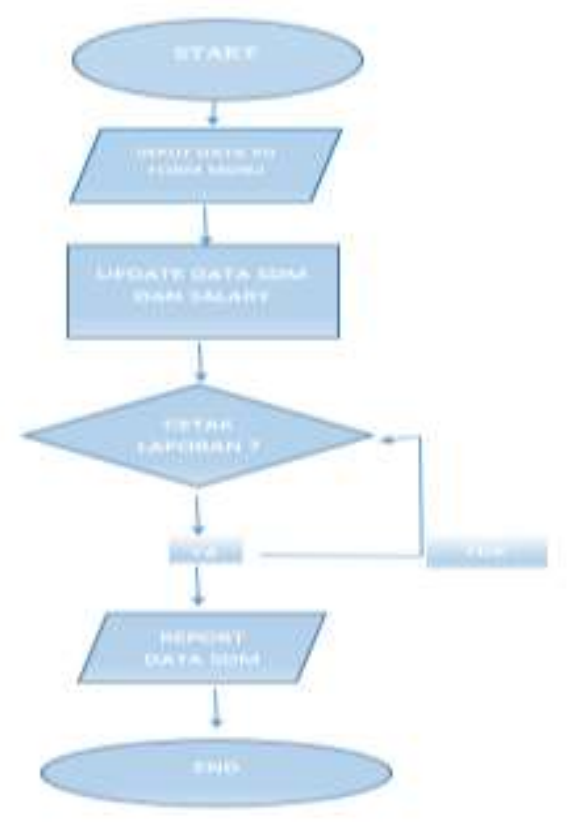

Gambar 2 Flowcart Sistem Aplikasi data sdm

b. Software yang digunakan untuk pembuatan sistem:

Perangkat yang diperlukan

Adapun beberapa Perangkat yang diperlukan dalam Perancangan Aplikasi Data SDM Untuk Penyedia Jasa Layanan BabySitter Dan ART yaitu:

a. Perangkat Keras

1. PC Desktop / Laptop

2. Printer untuk report data yang diinginkan
1. Database MySQL

2. Pemrograman desktop dengan menggunakan Powerbuilder.net

\section{HASIL DAN PEMBAHASAN}

Tampilan antar Muka Pengguna

Form Log in

\section{Sign up}

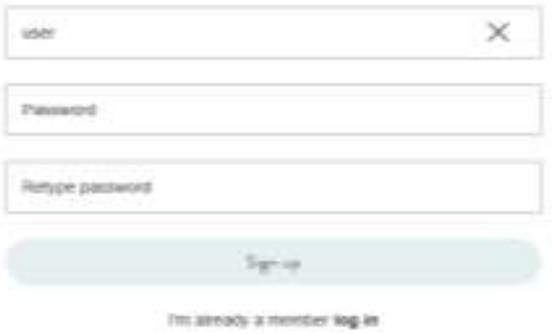

Gambar 3 Tampilan Form Log in Aplikasi SDM

Pada Form log in terdapat user, Pasword dan retype password yang dapat digunakan untuk masuk kemenu aplikasi 
Menu pada aplikasi

Menu Terdiri Dari File, Main Power, Referensi, Window, Report Help, Grafik Dan Tools
.Untuk menunjang kebutuhan data maka diperlukan pengisian Data Pribadi Pekerja seperti Identitas pekerja dan keterangan gaji yang bersangkutan.

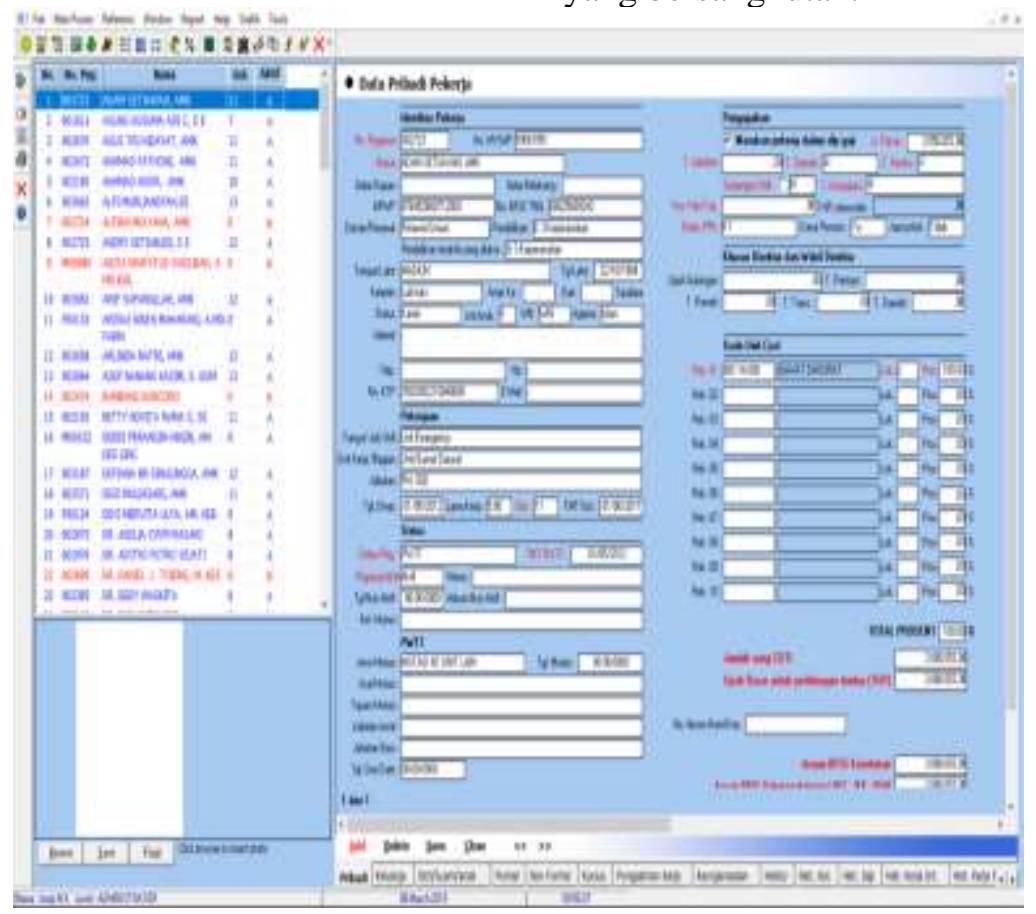

Gambar 4 Data Pribadi Pekerja

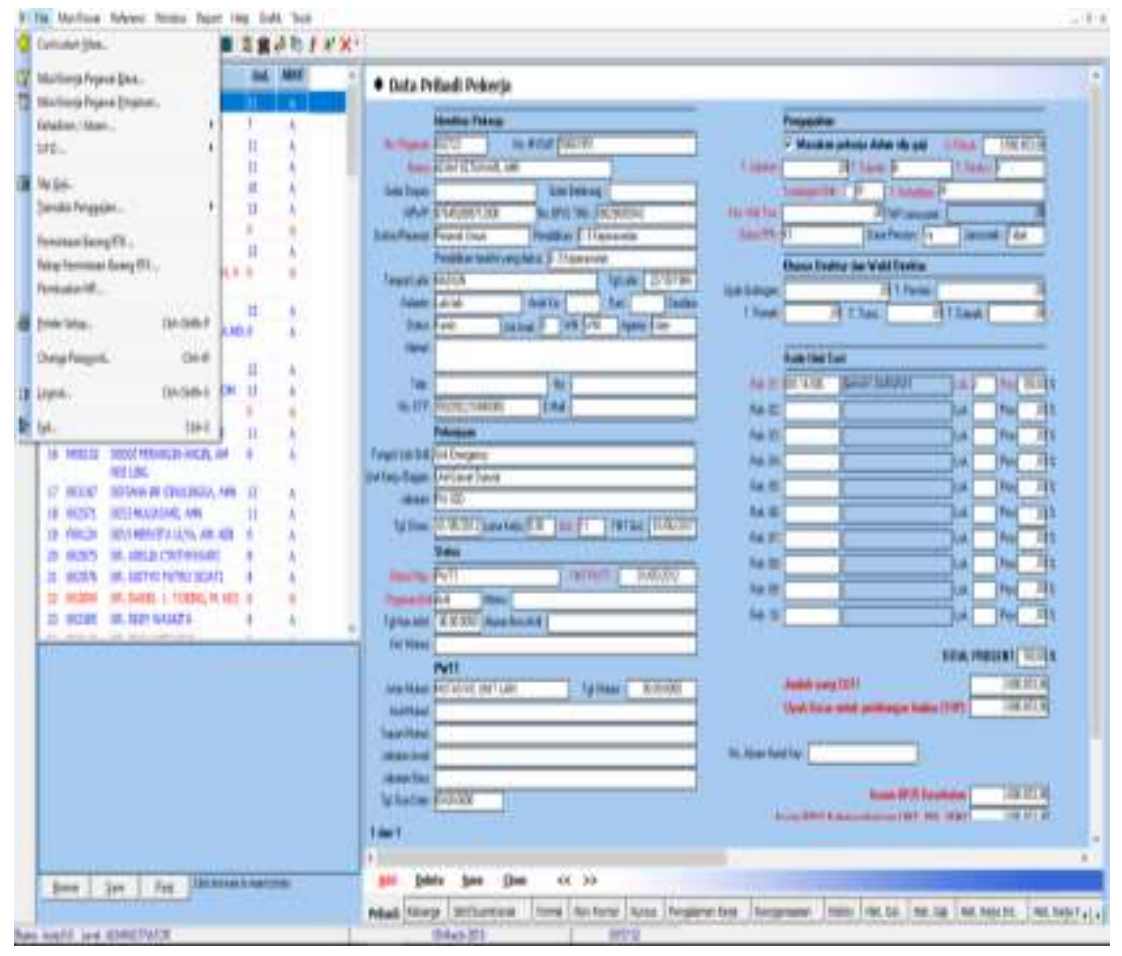

Gambar 5 Rincian menu File pada Aplikasi 
Menu File terdiri dari data Curiculum Vitae karyawan, Nilai Kinerja, Kehadiran/Absensi,

Slip Gaji dan sebagainya.

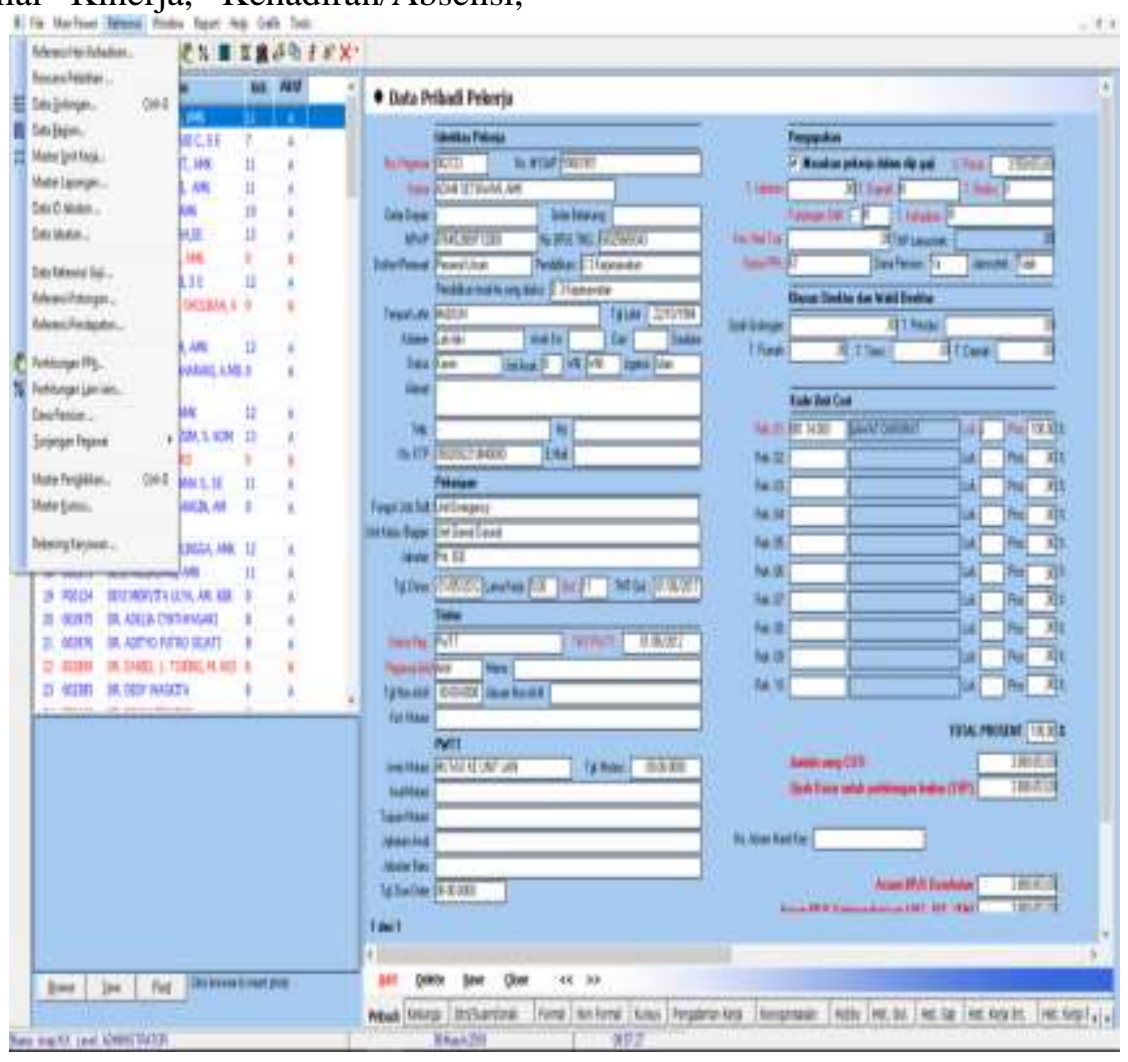

Gambar 6 Pilihan Menu Referensi

Pada menu Referensi terdapat pilihan referensi kehadiran, rencana pelatihan, data refensi gaji dan sebagainya 


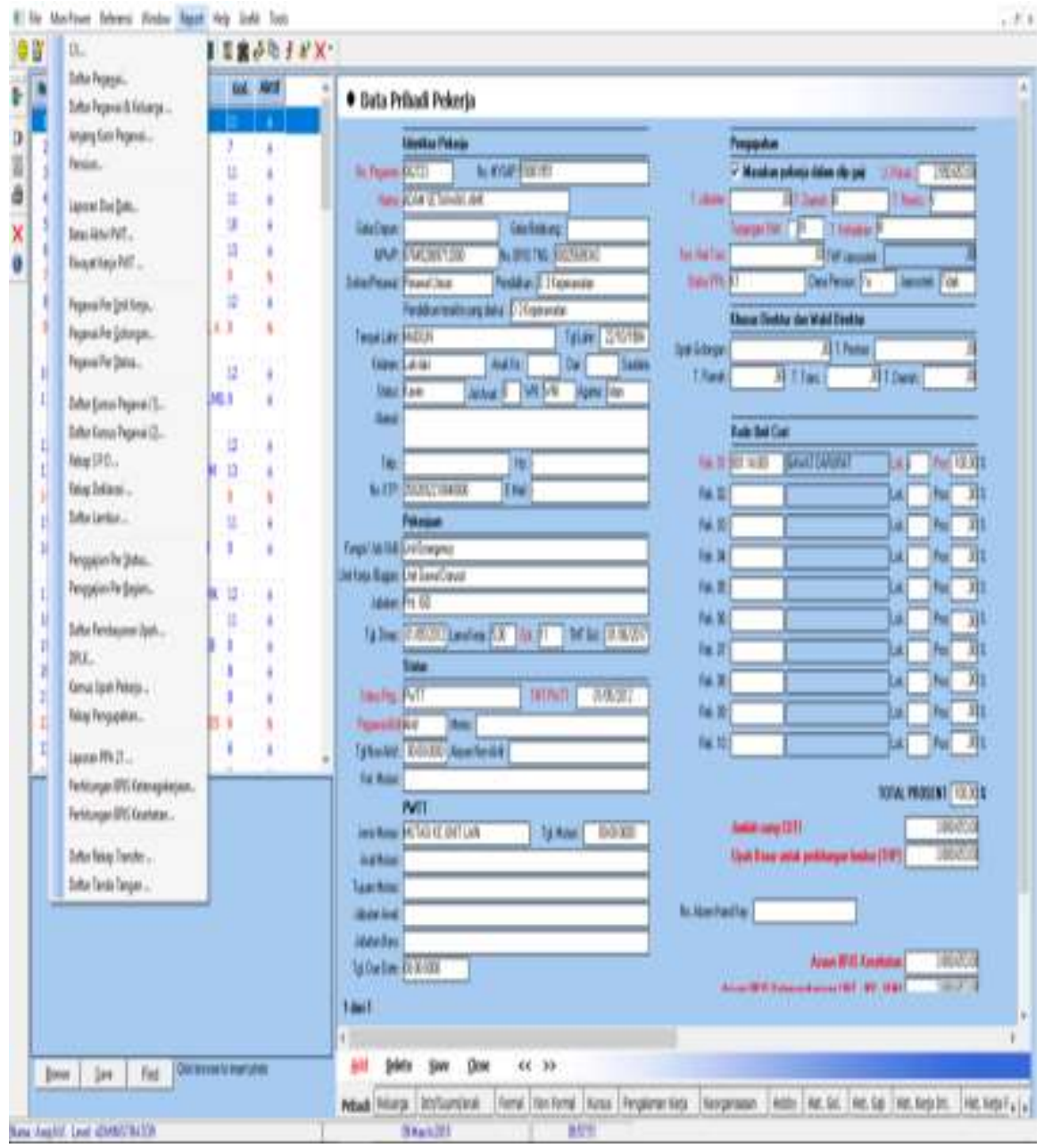

Gambar 7 Pilihan Menu Report

Pada menu Report kita dapat mengambil data CV, Data Pegawai , Daftar pembayaran Upah dan sebagainya.

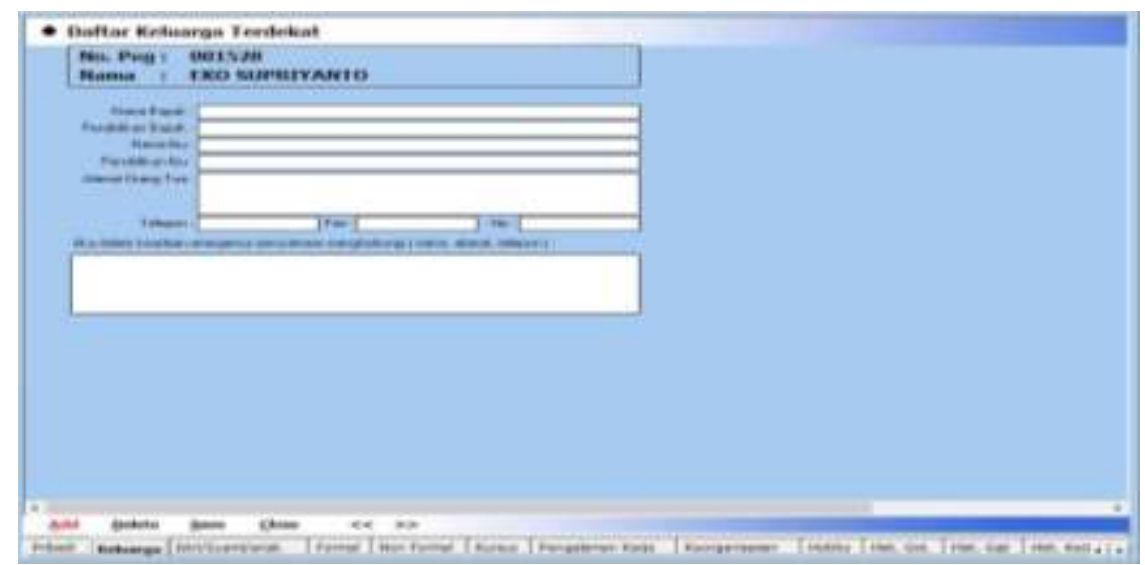

Gambar 8 Daftar Keluarga Terdekat 
Pada Menu Report juga terdapat Data Keluarga Terdekat karyawan yang bersangkutan lengkap dengan Alamat yang bisa dipertanggung jawabkan jika terjadi sesuatu yang tidak diinginkan misalnya Baby Sitter mencuri dirumah majikannya dan kemudian dia kabur. Jadi data keluarga terdekat sangat diperlukan pada aplikasi yang kami buat ini .

\section{KESIMPULAN}

Dari penelitian kami maka dapat disimpulkan untuk Aplikasi SDM untuk layanan Penyedia Baby Sitter dan asisten rumah tangga ini akan lebih memudahkan admin dalam mendata karyawan nya serta kemudahan untuk customer atau pengguna yang akan memakai jasa mereka dalam informasi data yang lebih akurat.

\section{Saran}

Untuk Memenuhi kebutuhan keamanan kedepannya Aplikasi dapat ditambahkan link yang dapat diakses secara online oleh Pihak Keamanan misalnya Kepolisian dan sebagai jika suatu saat terjadi Hal yang tidak diinginkan misalnya ada Baby Sitter atau Asisten rumah Tangga yang Berbuat Curang atau melakukan tindakan Kekerasan

\section{REFERENSI}

[1] Agus Hariayanto ,(2016).Membuat Aplikasi computer Base Test dengan PHP Mysql \& Bootratrap Penerbit Lokomedia.

[2] Al-Bahra bin Ladjamuddin.B, 2004 Konsep Sistem Basis Data dan Impementasinya. Graha Ilmu, Yogyakarta

[3] Jogiyanto, 1995 Pengantar Perancangan Sistem, Pengenalan Komputer, Erlangga,

[4] Rosa A.S, M.Shalahuddin, 2011 . Rekayasa Perangkat Lunak, Penerbit Modula, Bandung.

[5] Yuliusman Kurniawan, 2012 . Perancangan Sistem Informasi Pelayanan Medis Rawat Jalan Poliklinik Kebidanan dan Kandungan pada RSUD Kota Batam, Radiant Victor Imbar

[6]

http://www.aribherzi.my.id/2015/04/makalahtentang-power-builder.html diakses tanggal 20 juli 2017

[7]

http://www.aribherzi.my.id/2015/04/makalahtentang-power-builder.html diakses tanggal 30 september 2017 